\title{
TRANSFERRING NODD2, NODD3 GENES FROM RHIZOBIUM LEGUMINOSARUM, NIFH2 AND NIFH3 GENES FROM AZOTOBACTER CHROOCOCCUM TO BACILLUS MEGATERIUM
}

\author{
TAlABANI, SH. K. ${ }^{1 *}-$ KhIDER, A. K. ${ }^{2}-$ FATTAH, O. A. ${ }^{1}$ \\ ${ }^{1}$ Soil and Water Sciences Department, College of Agricultural Sciences, University of \\ Sulaimani, Sulaimani, Kurdistan Region of Iraq \\ (e-mail: omar.fattah@univsul.edu.iq; phone: +964-770-153-6011) \\ ${ }^{2}$ Biology Department, College of Education Scientific, University of Salahaddin, Erbil, \\ Kurdistan Region of Iraq \\ (e-mail: dradelkamal51@yahoo.com phone: +964-750-447-2908) \\ *Corresponding author \\ e-mail: shahen.fazil@univsul.edu.iq; phone: +964-770-158-6531 \\ (Received 25 $5^{\text {th }}$ May 2019; accepted $10^{\text {th }}$ Sep 2019)
}

\begin{abstract}
The present study aimed to transfer nod and nif genes from Rhizobium and Azotobacter to Bacillus by: the transformation technique which used to transfer nod $\mathrm{D} 2$ and nod $\mathrm{D} 3$ from Rhizobium leguminosarum to Bacillus megaterium; and the conjugation mechanism which performed the transfer of $n i f \mathrm{H} 2$ and nifH3 from Azotobacter chroococcum to transformant Bacillus megaterium. The results showed that: 12 colonies were obtained after transformation on Sperber's agar plates which contained tetracycline and ampicillin. While after conjugation; 166 colonies were obtained on Sperber's agar plates which contained ampicillin and erthymycinem, indicating that the transformation and conjugation were successful. To confirm this, a molecular study was performed based on the followings: the extraction of the plasmid DNA from Rhizobium leguminosarium and transformant Bacillus megaterium to detect nodD genes; and the extraction of the genomic DNA from Azotobacter chroococcum and transformantconjugant Bacillus megaterium to detect nifH genes by PCR and gel electrophoresis. The PCR products on gel electrophoresis showed that Rhizobium leguminosarium and transformant Bacillus megaterium contained nod $\mathrm{D} 2$ and nod $\mathrm{D} 3$; and Azotobacter chroococcum and transformant-conjugant Bacillus megaterium contained nif $\mathrm{H} 2$ and nif $\mathrm{H} 3$. Furthermore, the new Bacillus megaterium which obtained these genes successfully, can be used as biofertilizer for nitrogen fixation and phosphorus solubilization at the same time.
\end{abstract}

Keywords: nod gene, nif gene, DNA transferring, PCR, Gel electrophoresis

\section{Introduction}

Rhizobium and Azotobacter interact with a wide range of other soil microorganisms in the rhizosphere of plants. These interactions are sometimes stimulatory where they increase the growth response of the host in the presence of other microorganisms (Kennedy and Islam, 2001; Nosheen et al., 2011). Azotobacter and Rhizobium are known to be good non-symbiotic and symbiotic nitrogen fixers, respectively (Siddiqui et al., 2014). This biological nitrogen fixation process in Azotobacter, and between Rhizobium strains and their legume partners can happen under low levels of available nitrogen with the help of many different genes such as nod, nif, fix, production of polysaccharides, competition, infection process, and host specificity (Shamseldin, 2013). Rhizobium nod genes, and their product, Nod Factor (NF), have been recognized as essential for the development of nitrogen-fixing nodules on legume roots (Lerouge et al., 1990). NodD is present in all rhizobia (Shamseldin, 2013). NodD is the core signaling protein, reacting to 
plant flavonoids then binding to nod boxes, binding sites upstream of nod genes, typically $\operatorname{nod} \mathrm{A}$ and/or $\operatorname{nod} \mathrm{B}$, trigger the expression of a nod gene cascade and thus the construction of the Nod Factor (Jones et al., 2007). The nif genes are able to fix nitrogen in both the free-living and symbiotic states, and the nif genes can transcript in both free-living and symbiotic diazotrophs (Dixon and Kahn, 2004). The expression and regulation of nif genes, while sharing common features in all or most of the nitrogen-fixing organisms in nature, have distinct characteristics and qualities that differ from one diazotroph to another (Spaink et al., 1998). The structural gene nifH, as an important nif gene, is involved in the formation of the Fe-protein complex (Cocking, 2003), and nifH is the gene that encodes the iron protein subunit of nitrogenase, which is highly conserved among all nitrogen-fixing groups and serves as an ideal molecular marker for these microorganisms (Deslippe and Egger, 2006). Bacillus megaterium has the ability to solubilize phosphorus, which is good for the plant (Velineni and Brahmaprakash, 2011). Bacillus megaterium produces organic compounds such as lactic acid, gluconic acid, citric acid, succinic acid, propionic acid and enzymes that help solubilize the fixed phosphorus into exchangeable form (Agrilife, 2008).

In the bacterial population, DNA can be transferred from one organism to another by the horizontal transfer mechanism. The DNA thus transferred by the lateral/horizontal method can be stably incorporated in the recipient, and changes the genetic composition of the recipient permanently. Three broad mechanisms mediate efficient movement of DNA between cells: transformation, conjugation, and transduction (Acharya, 2013). Bacterial plasmid transformation is a process by which genetic material, often a plasmid, is inserted into a bacterial cell. Though transformation does occur naturally, scientists have developed many techniques to ensure DNA uptake by bacterial cells (Yoo, 2010). Genetic transformation occurs when a cell takes up (takes inside) and expresses a new piece of genetic material-DNA, and it literally means change caused by genes and involves the insertion of one or more gene(s) into an organism in order to change the organism's traits, this new genetic information often provides the organism with a new trait which is identifiable after transformation (www.explorer.bio-rad.com). Transformation takes place to a limited extent in many bacteria. But laboratory techniques have been developed that increase the rate of DNA uptake. (www.kullabs.com). Bacterial transformation is a process which involves genetic alteration of bacteria by the incorporation and stable expression of foreign genetic material from the environment or surrounding medium. Since DNA is a very hydrophobic molecule, it will not normally pass through a bacterial cell membrane. In order to uptake foreign DNA, the bacterial cells must first be made competent. Competence is the ability of a cell to take up extracellular DNA from its environment (www.himedialabs.com. a). In bacteria, the haploid genome is a single circular chromosome. This differs from eukaryotic genomes like those of plants and animals, where the genetic material is diploid and arranged into linear chromosomes. Bacteria can also possess additional nonessential pieces of circular DNA called plasmids (www.towson.edu/cse). Plasmids are small circles of DNA that contain an origin of replication (ori) and a small number of genes, some of which may confer a survival advantage on a host. Some plasmids can transfer between different species; even between different kingdoms (Slonczewski, 2006). Plasmid transformation into bacterial competent cells is a key technique in molecular cloning (Tu et al., 2005).

Many bacteria from different species frequently exchange their genetic materials by a process called conjugation, which occurs by cell-to-cell contact (Fernandez-Lopez et al., 
2005). Conjugation is a recombination process where two live bacteria come together, and the donor cell transfers genetic material to the recipient cell. Conjugating bacteria are of two mating types. Certain "male" types (designated as F+) donate their DNA, and other "female types" (designated as F-) receive the DNA, F- cells become F + when they acquire a small amount of DNA. Hence the F factor is called as the Fertility factor. In contemporary microbiology, the donor's F factors are known to be plasmids which are extra-chromosomal elements. The factors (plasmids) contain about 20-30 genes, most of which are associated with conjugation. These genes encode enzymes that replicate DNA during conjugation and structural proteins needed to synthesize special pili at the cell surface which known as F pili or sex pili, these hair-like fibers contact the recipient bacteria, and then retract so that the surfaces of donor and recipient are very close or touching one another. At the area of contact, a channel or conjugation bridge is formed. Once contact via sex pili has been made, the $\mathrm{F}$ factor (plasmid) begins replicating by the rolling circle mechanism. A single strand of the factor then passes over or through the channel to the recipient. When it arrives, enzymes synthesize a complementary strand, and a double helix is formed. The double helix bends to a loop and reforms an $\mathrm{F}$ factor (plasmid), thereby completing the conversion of the recipient from F- cell to F + cell. Meanwhile, back in the donor cell a new strand of DNA forms, to complement the leftover strand of the $\mathrm{F}$ plasmid. The transfer of $\mathrm{F}$ factors involves no activity of the bacterial chromosome; therefore the recipient does not acquire new genes other than those on the F factor (www.himedialabs.com).

Transformation process holds key step in molecular biology (Das et al., 2017), and it has been a handy tool in several areas of bacterial research because the genotype of a strain can be deliberately changed in a very specific way by transforming with an appropriate DNA fragment. For example, transformation is used widely in genetic engineering (Pimda and Bunnag, 2010). The goals of gene transfer experiments with other organisms are to study gene regulation and to obtain stable inheritance and expression of new characteristics (Moses, 1987).

Conjugation gene transfer is considered to be an important mechanism for the establishment of new genetic traits in diverse environments (Hausner and Wuertz, 1999). Conjugation is used in nature to share beneficial genetic material between bacteria, such as antibiotic resistance. However, manually inserting genes into the Fplasmid would allow for scientists to have bacteria transfer almost any gene to other cells (Griffiths et al., 2000).

\section{Materials and methods}

\section{The country and location of the study}

The present study was performed in Sulaimani city/Iraq. All bacteria were isolated from the organic farm of Bakrajow, and the molecular studies were done at the laboratories. The farm and the laboratories are located inside the College of Agricultural Sciences, University of Sulaimani.

\section{Isolation of bacteria}

Rhizobium leguminosarium spp. were isolated from healthy, unbroken, firm and pink nodules of Broad bean from the organic farm of Bakrajow using YMA medium in accordance with Agrawal et al., 2012, while Azotobacter chroococcum spp. were 
isolated from Bakrajow soil on modified Ashby's medium according to Marwa et al., 2010, and Bacillus megaterium was isolated from same soil using Sperber's medium based on Shiva et al., 2010.

\section{Purification of isolated bacteria}

A loop of actively growing of each bacterial species ( $48 \mathrm{~h}$ old surface film) was streaked on their selective media, the growth was observed depending on the type of bacteria, $R$. leguminosarium and B. megaterium after $24-48 \mathrm{~h}$ and $A$. chroococcum after 3-7 days at $28{ }^{\circ} \mathrm{C}$ of incubation. The well separated and apparently un-contaminated colonies appearing on the plates were streaked on agar medium, plating and picking were repeated at least 4-5 times.

\section{Maintenance and storage of bacterial culture}

The cultures were maintained for a short time at slant medium, and for a long time in $20 \%$ glycerol and stored at $-70{ }^{\circ} \mathrm{C}$ (Ausabel et al., 2003) without losing their activity.

\section{Identification of bacteria by molecular protocol}

Depending on the molecular protocol, B. megaterium was identified by the extraction of genome DNA using PrestoTM Mini gDNA Bacteria Kit Protocol to detect and check the presence of $B$. megaterium in the region by two random primers, $R$. leguminosarium was identified by the extraction of plasmid DNA using Genetbio, PrmePrep Plasmid DNA isolation kit to detect the nodD2 and nodD3 genes which we wanted to transfer to the B. megaterium by the transformation process, and A. chroococcum was identified by extraction of genomic DNA using PrestoTM Mini gDNA Bacteria Kit Protocol to detect the nif $\mathrm{H} 2$ and nif $\mathrm{H} 3$ genes which we wanted to transfer to the transformant $B$. megaterium by the conjugation process using specific primers for each gene in order to obtain a new model of the $B$. megaterium which would contain both of the nod and nif genes and then could be used as bio-fertilizers to provide available nitrogen and phosphorus to plants.

\section{PCR amplification conditions}

The conditions of PCR amplification: for nod $\mathrm{D} 2$ and nodD3 were performed according to the modified method of Del Cerro et al., 2015a at cycling conditions consisted of a single cycle of $95^{\circ} \mathrm{C}$ for $10 \mathrm{~min}$, followed by 45 cycles of $95{ }^{\circ} \mathrm{C}$ for $2 \mathrm{~min}, 60{ }^{\circ} \mathrm{C}$ for $30 \mathrm{~s}$ and $72{ }^{\circ} \mathrm{C}$ for $30 \mathrm{~s}$, and a final extension cycle at $72{ }^{\circ} \mathrm{C}$ for $6 \mathrm{~min}$, while PCR reactions for nifH 2 and nifH3 were done in accordance with Setubal et al., 2009), and for random primers 1 and 2 of B. megaterium was carried out in accordance with Patil et al., 2013). The forward, reverse and random primers are shown in Table 1.

\section{Gel electrophoresis (Helmut et al., 2004)}

Gel electrophoresis was used to identify the extraction of each of genome DNA, chromosomal DNA, and plasmid DNA, and it was also used to check the DNA amplification of each product by dissolving $0.5,1,1.5$ and $2 \%(\mathrm{w} / \mathrm{v})$ of agarose gel depending on the size of amplified DNA in $100 \mathrm{ml}$ (IX) TBE buffer by heating it in a micro-wave oven for $3 \mathrm{~min}$, then cooling the solvent to $45^{\circ} \mathrm{C}$ at room temperature. The gel was stained with $5 \mu \mathrm{l}$ of $5 \mathrm{mg} \cdot \mathrm{ml}^{-1}$ ethidium bromide, and the gel was soaked in a 
gel tank containing TBE. The gel tank was covered by a lid, and electrophoresis was run at $(80$ to $100 \mathrm{~V})$ for $2-3 \mathrm{~h}$ depending on the product. DNA fragments were visualized at $312 \mathrm{~nm}$ with a UV- transilluminator image.

Table 1. The forward, reverse and random primers used

\begin{tabular}{c|c|c|c}
\hline Primer & Sequence (5'-3') & Nucleotide & Reference \\
\hline nodD2- F- & (GTA GGC CAT AAT GTC CAG A) & 19 & \multirow{2}{*}{ Del Cerro et al., 2015a } \\
nodD2- R- & (GCG GCT TTA TAC TCA CCA) & 18 & \\
\hline nodD3- F- & (GAG CTA CCT CGA CTG CTA) & 18 & \multirow{2}{*}{ Del Cerro et al., 2015b } \\
nodD3- R- & (CTA CCG CCA TGA TCA CCA) & 18 & \\
\hline nifH2- F- & (CGCCGGCGCAGTGTTTGCGG) & 20 & \multirow{2}{*}{ Setubal et al., 2009 } \\
nifH2 -R- & (CACTCGTTGCAGCTGTCGGC) & 20 & \multirow{2}{*}{ Setubal et al., 2009 } \\
\hline nifH3- F- & (CGATGACTGAAGACTGAACGAG) & 22 & \multirow{2}{*}{ Patil et al., 2013 } \\
nifH3 -R- & (AAGGTGCGGTCAGGAGAGAA) & 20 & 10 \\
\hline Random primer1 & (GGT GCG GGA A) & 10 & \\
Random primer2 & (GTA GTC ATA T) & &
\end{tabular}

\section{Antibiotics resistance test}

Table 2 shows the 8 common antibiotics including Chloramphenicol, Gentamycin, Tetracycline, Ampicillin, Cefotaxim, Erthymycine, Streptomycin and Rifampicin which were used for testing the sensitivity of: $R$. leguminosarium and B. megaterium for transformation technique, and transformant B. megaterium and A. chroococcum for conjugation process.

Table 2. The antibiotics used in accordance with Shoukry et al., 2013; American Type Culture Collection, 2013; Giacopello et al., 2016

\begin{tabular}{c|c|c}
\hline Antibiotic & Recommended stock concentration & Recommended working concentration \\
\hline Chloramphenicol & $10 \mathrm{mg} / \mathrm{ml}$ in ethanol & $25 \mu \mathrm{g} / \mathrm{mL}$ \\
Gentamycin & $10 \mathrm{mg} / \mathrm{ml}$ & $10 \mu \mathrm{g} / \mathrm{mL}$ \\
Tetracycline & $10 \mathrm{mg} / \mathrm{ml} \mathrm{in}(50 \% \mathrm{D} . W+50 \%$ ethanol $)$ & $10 \mu \mathrm{g} / \mathrm{mL}$ \\
Ampicillin & $10 \mathrm{mg} / \mathrm{ml}$ in water & $20 \mu \mathrm{g} / \mathrm{ml}$ \\
Cefotaxime & $10 \mathrm{mg} / \mathrm{ml}$ in water & $30 \mu \mathrm{g} / \mathrm{ml}$ \\
Erthymycine & $10 \mathrm{mg} / \mathrm{ml}$ in water & $15 \mu \mathrm{g} / \mathrm{ml}$ \\
Streptomycin & $10 \mathrm{mg} / \mathrm{ml}$ in water & $10 \mu \mathrm{g} / \mathrm{ml}$ \\
Rifampicin & $10 \mathrm{mg} / \mathrm{ml}$ in methanol & $5 \mu \mathrm{g} / \mathrm{ml}$ \\
\hline
\end{tabular}

\section{Preparation of competent cells from $B$. megaterium}

A modified method of Sambrook et al., 1989 was used for the preparation of competent cells of $B$. megaterium for transformation. An overnight culture of $B$. megaterium was prepared by suspending a colony from a fresh Sperber's plate in $100 \mathrm{ml}$ of Sperber's broth medium. The culture was incubated in a shaking incubator at $100 \mathrm{rpm}$ for $24 \mathrm{~h}$ at $28^{\circ} \mathrm{C}$, then $10 \mathrm{ml}$ of this culture was suspended in $90 \mathrm{ml}$ of 
fresh Sperber's broth and grown at $28{ }^{\circ} \mathrm{C}$ for $90 \mathrm{~min}$ in a shaking incubator until an OD $600 \mathrm{~nm}$ of approximately 0.3-0.6 was attained, then $10 \mathrm{ml}$ aliquots was centrifuged at $4000 \mathrm{Xg}$ for $10 \mathrm{~min}$ at $4{ }^{\circ} \mathrm{C}$ to pellet the cells. After that, the supernatant was discarded and cells were re-suspended in $10 \mathrm{ml}$ of $0.1 \mathrm{M} \mathrm{CaCl}_{2}$ over $1 \mathrm{~h}$ on ice, and re-centrifuged twice, following the third washing with $5 \mathrm{ml} 0.1 \mathrm{M} \mathrm{CaCl}_{2}$. Finally the cells were re-centrifuged and gently re-suspended in $2 \mathrm{ml}$ of ice-cold $0.1 \mathrm{M} \mathrm{CaCl}_{2}$ containing $20 \%$ glycerol. The cells could be used immediately for transformation or stored at $-20{ }^{\circ} \mathrm{C}$.

\section{Bacterial transformation (Ausabel et al., 2003)}

A total of $200 \mu \mathrm{l}$ of competent cells (B. megaterium) were mixed with $2 \mu 1$ of the extracted plasmid from $R$. leguminosarium in a tube, and the tube was left on ice for $30 \mathrm{~min}$. After that the tube was incubated for $30 \mathrm{~s}$ at $42{ }^{\circ} \mathrm{C}$ in a water bath and then placed on ice for $5 \mathrm{~min}$, then $800 \mu \mathrm{l}$ of Sperber's broth was added and the tube was incubated at $28^{\circ} \mathrm{C}$ for $1 \mathrm{~h}$. Then the cells were centrifuged at $6000 \mathrm{Xg}$ for $1 \mathrm{~min}$. Next, the pellet was re-suspended in $200 \mu \mathrm{l}$ of Sperber's broth. A total of $100 \mu \mathrm{l}$ of the cells were plated out on Sperber's agar medium containing two antibiotics which were used as genetic markers. After post-incubation at $28^{\circ} \mathrm{C}$ for $28 \mathrm{~h}$ the colonies were screened, then the molecular study was performed using PCR and gel electrophoresis techniques for detection of transferred nod 22 and nod 3 genes in transformant $B$. megaterium that transferred by transformation process.

\section{Bacterial conjugation (Olsen et al., 1992)}

A $10 \mathrm{ml}$ of modified Ashby's broth medium was inoculated with a single colony of A. chroococcum (donor cell), and $10 \mathrm{ml}$ of Sperber's broth medium was inoculated with a single colony of transformant $B$. megaterium (recipient cell), then they were incubated at $28{ }^{\circ} \mathrm{C}$ for $48 \mathrm{~h}$. with shaking at $100 \mathrm{rpm}$. After incubation, $0.8 \mathrm{ml}$ of the A. chroococcum (donor cells) were mixed with $0.2 \mathrm{ml}$ of transformant B. megaterium (recipient cells) and $1 \mathrm{ml}$ of Sperber's broth, the mixture was incubated at $28{ }^{\circ} \mathrm{C}$ for $3 \mathrm{~h}$ under aerobic condition. Then $0.1 \mathrm{ml}$ of the conjugated mixture was spread on Sperber's agar medium plates containing two antibiotics that were used as genetic markers, and control plates were prepared by spreading $0.1 \mathrm{ml}$ for each donor and recipient suspensions separately on agar plates containing the same markers, then all plates were incubated at $28{ }^{\circ} \mathrm{C}$ till the colonies appeared. To verify the transfer of nitrogen fixation genes (nif genes) from $A$. chroococcum to transformant $B$. megaterium, the transformant-conjugant colonies were screened, then the molecular study was performed using PCR and gel electrophoresis techniques for the detection of transferred nif $\mathrm{H} 2$ and nif $\mathrm{H} 3$ genes, that were transferred by conjugation process, in transformant-conjugant $B$. megaterium.

\section{Results}

\section{DNA isolation from bacteria}

The DNA was isolated from bacterial cultures, and the molecular method based on the extraction of the genomic DNA from A. chroococcum and B. megaterium and plasmid DNA from $R$. leguminosarium, which were detected by agarose gel electrophoresis, the results are shown in Figure 1 lane 2, 4, 6 respectively. 


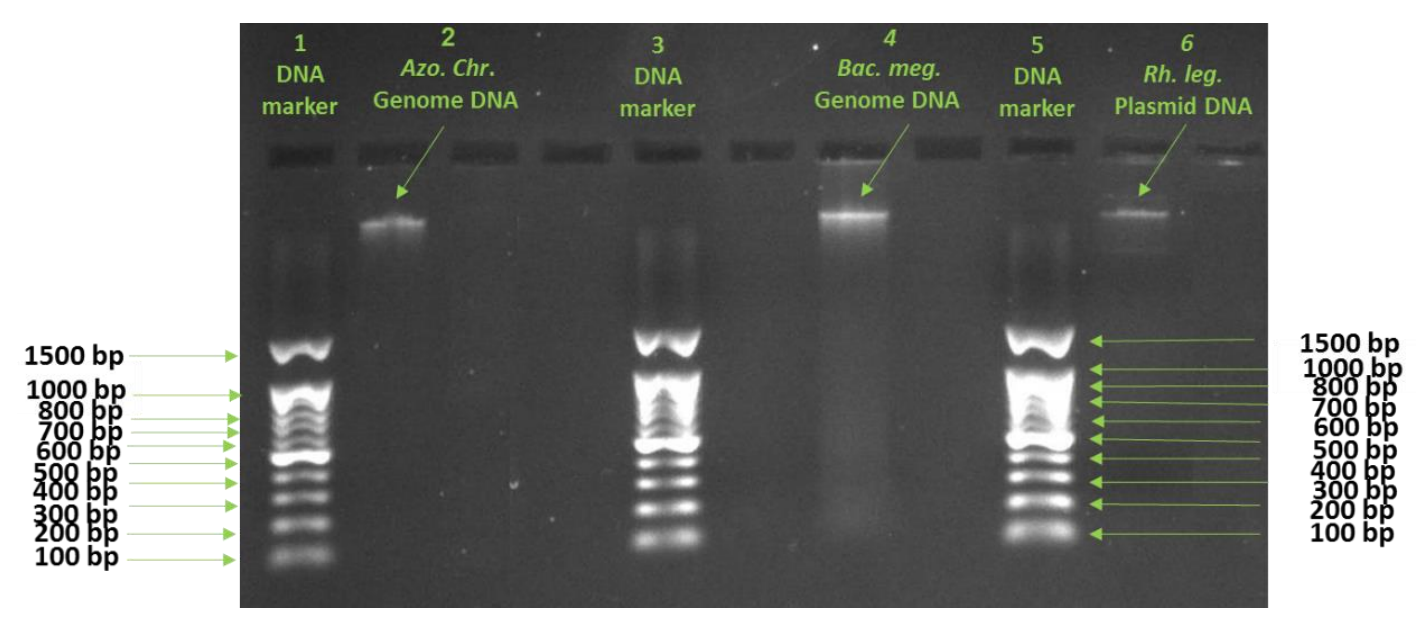

Figure 1. Agarose gel electrophoresis shows DNA marker lanes 1, 3, and 5, extracted chromosomal DNA from A. chroococcum, genome DNA from B. megaterium and plasmid DNA from $R$. leguminosarium lanes 2, 4 and 6, respectively

\section{Molecular based identification of Bacillus megaterium}

The PCR amplification was performed to check the presence of B. megaterium in the region using two random primers. The PCR products showed high amplification rate and reproducible banding pattern which confirmed the existence of $B$. megaterium (Fig. 2, lanes 2 and 3).

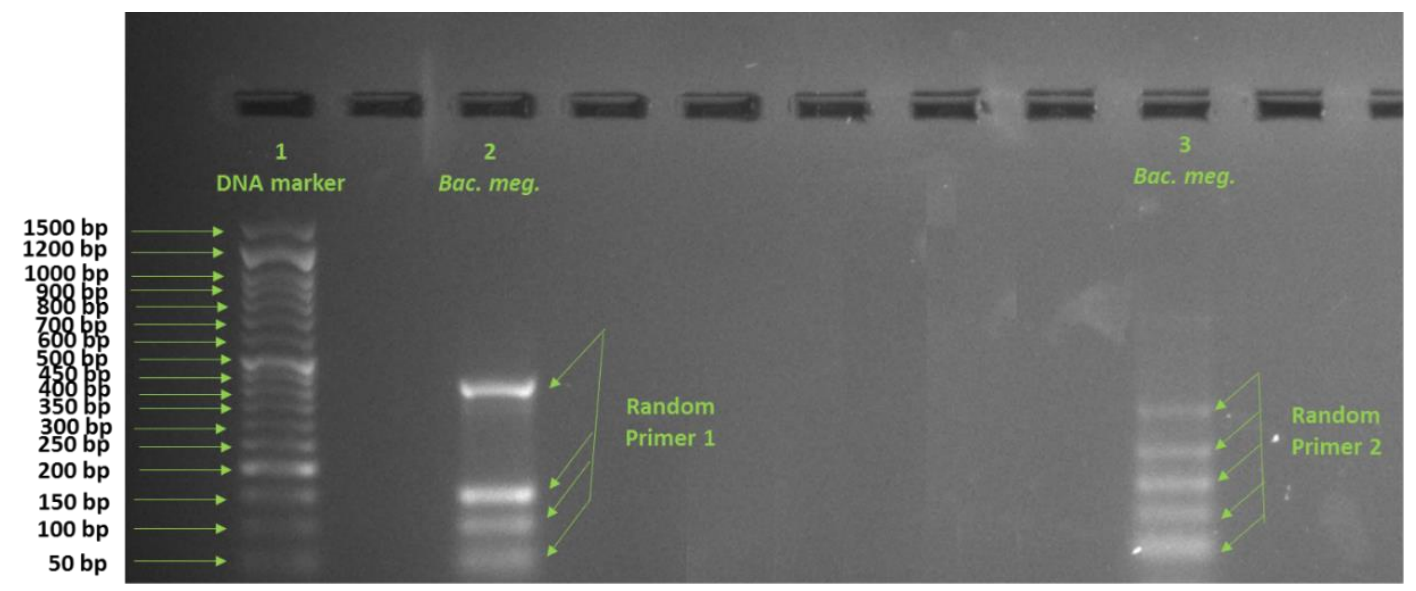

Figure 2. Agarose gel electrophoresis shows the PCR amplified products of the B. megaterium generated using 10-mer random primers: Lane 1: DNA marker, lanes 2 and 3: random primers 1 and 2 respectively (+ve PCR products)

\section{Antibiotics resistance of $R$. leguminosarium, $B$. megaterium, transformant $B$. megaterium and $A$. chroococcum}

The resistance screening of $R$. leguminosarium, B. megaterium, Transformant $B$. megaterium, and $A$. chroococcum was evaluated for eight antibiotics that are widely used. Depending on the results in a Table 3, tetracycline and ampicillin were used as genetic markers for transformation experiment, while ampicillin and erthymycine were used as genetic markers for the conjugation experiment. 
Table 3. Antibiotics Resistance of R. leguminosarium, B. megaterium, Transformant B. megaterium and A. chroococcum

\begin{tabular}{c|c|c|c|c}
\hline Antibiotic & R. leguminosarium & B. megaterium & Transformant B. megaterium & A. chroococcum \\
\hline Chloramphenicol & $\mathrm{R}$ & $\mathrm{S}$ & $\mathrm{R}$ & $\mathrm{R}$ \\
Gentamycin & $\mathrm{R}$ & $\mathrm{S}$ & $\mathrm{R}$ & $\mathrm{S}$ \\
Tetracycline & $\mathrm{S}$ & $\mathrm{R}$ & $\mathrm{R}$ & $\mathrm{R}$ \\
Ampicillin & $\mathrm{R}$ & $\mathrm{S}$ & $\mathrm{S}$ & $\mathrm{R}$ \\
Cefotaxim & $\mathrm{R}$ & $\mathrm{S}$ & $\mathrm{R}$ & $\mathrm{S}$ \\
Erthymycine & $\mathrm{R}$ & $\mathrm{R}$ & $\mathrm{R}$ & $\mathrm{S}$ \\
Streptomycin & $\mathrm{R}$ & $\mathrm{S}$ & $\mathrm{R}$ & $\mathrm{S}$ \\
Rifampicin & $\mathrm{R}$ & $\mathrm{S}$ & $\mathrm{R}$ & $\mathrm{R}$ \\
\hline
\end{tabular}

$\mathrm{S}=$ Sensitive $\mathrm{R}=$ Resistance

\section{Transformation of plasmid genes (nodD2 and nodD3) from R. leguminosarium to B. megaterium by transformation process}

Transformation experiment was carried out to transfer the genes responsible for the nodulation (nod $\mathrm{D}$ genes) which were nod $\mathrm{D} 2$ and nod $\mathrm{D} 3$ from $R$. leguminosarium to $B$. megaterium. After the transformation, 12 colonies were gained on Sperber's medium supplied with tetracycline and ampicillin as genetic markers and the colonies were resistant to both antibiotics. These results confirmed that the resulting colonies were transformant colonies and the transformation technique was successful between $R$. leguminosarium and B. megaterium. To confirm if nod 2 and nodD3 genes transferred from $R$. leguminosarium to $B$. megaterium by transformation technique, the molecular study was performed using specific primers to detect the nodD2 and nodD3 genes in transformant cells and compared to the nod $\mathrm{D} 2$ and nod $\mathrm{D} 3$ genes in $R$. leguminosarium by PCR technique and gel electrophoresis.

\section{PCR amplification of nodD2 and nodD3}

After extraction and purification of plasmid DNA from $R$. leguminosarium, $B$. megaterium and transformant $B$. megaterium using the Genetbio, PrmePrep Plasmid DNA isolation kit according to the manufacturer's protocol, PCR and gel electrophoresis were carried out in order to amplify and check the existenc of nodD2 and nodD3 in the plasmid DNA of $R$. leguminosarium, $B$. megaterium and transformant $B$. megaterium using specific oligonucleotide primers that flank the DNA sequence to be amplified.

Figure 3 shown positive PCR products on gel electrophoresis in $R$. leguminosarium and transformant $B$. megaterium which contained nod $\mathrm{D} 2-\mathrm{F}$ - and nodD2-R-primers with 100 bp in lanes 2 and 4, respectively, while in Figure 4, the results show the positive amplification on gel electrophoresis of nodD3 in $R$. leguminosarium and transformant $B$. megaterium with $150 \mathrm{bp}$ in lanes 2 and 4, respectively using nodD3-F- and nodD3-R-primers, but the negative control and $B$. megaterium were negative PCR products and they did not produce bands, which can be seen in lanes 3 and 5, respectively in Figures 3 and 4. 


$$
-14017 \text { - }
$$

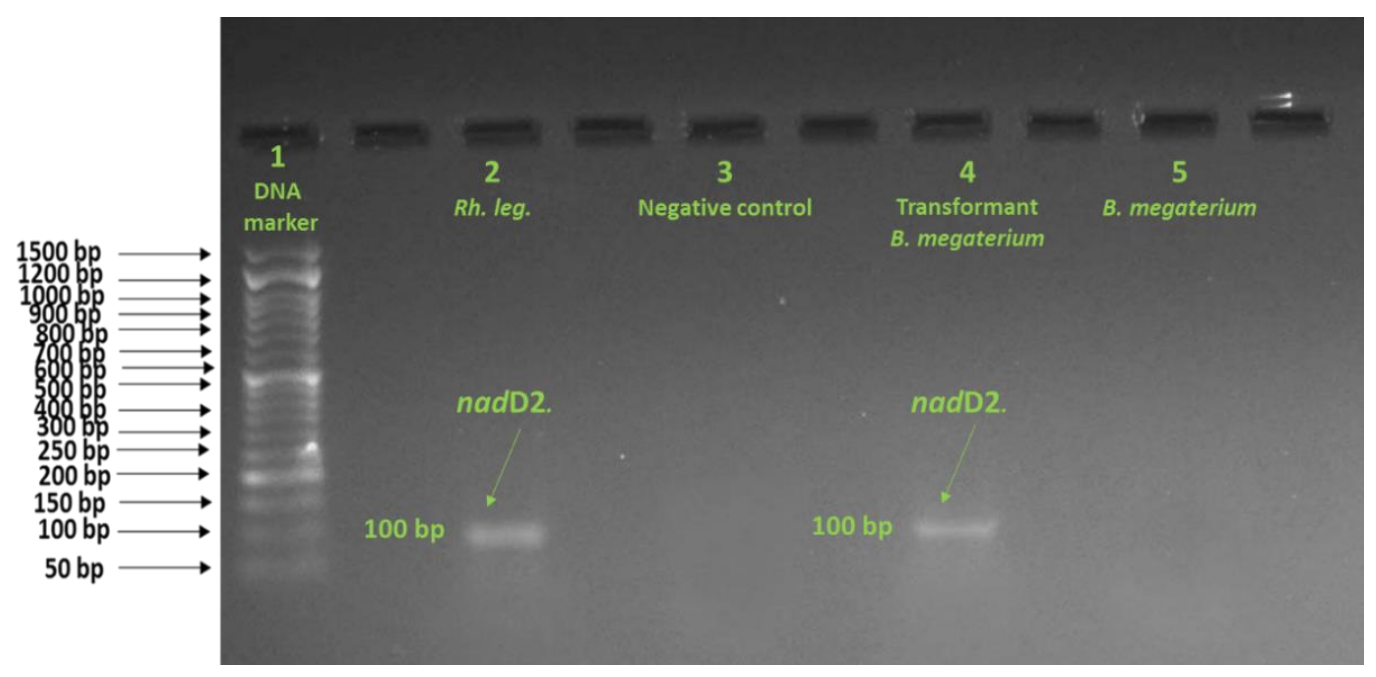

Figure 3. Agarose gel electrophoresis shows the PCR amplified products of the nodD2 gene (100 bp). Lane 1: DNA marker, lane 2: R. leguminosarium (+ve PCR product), lane 3: negative control (-ve PCR product), lane 4: transformant B. megaterium (+ve PCR product) and lane5:

B. megaterium (-ve PCR product)

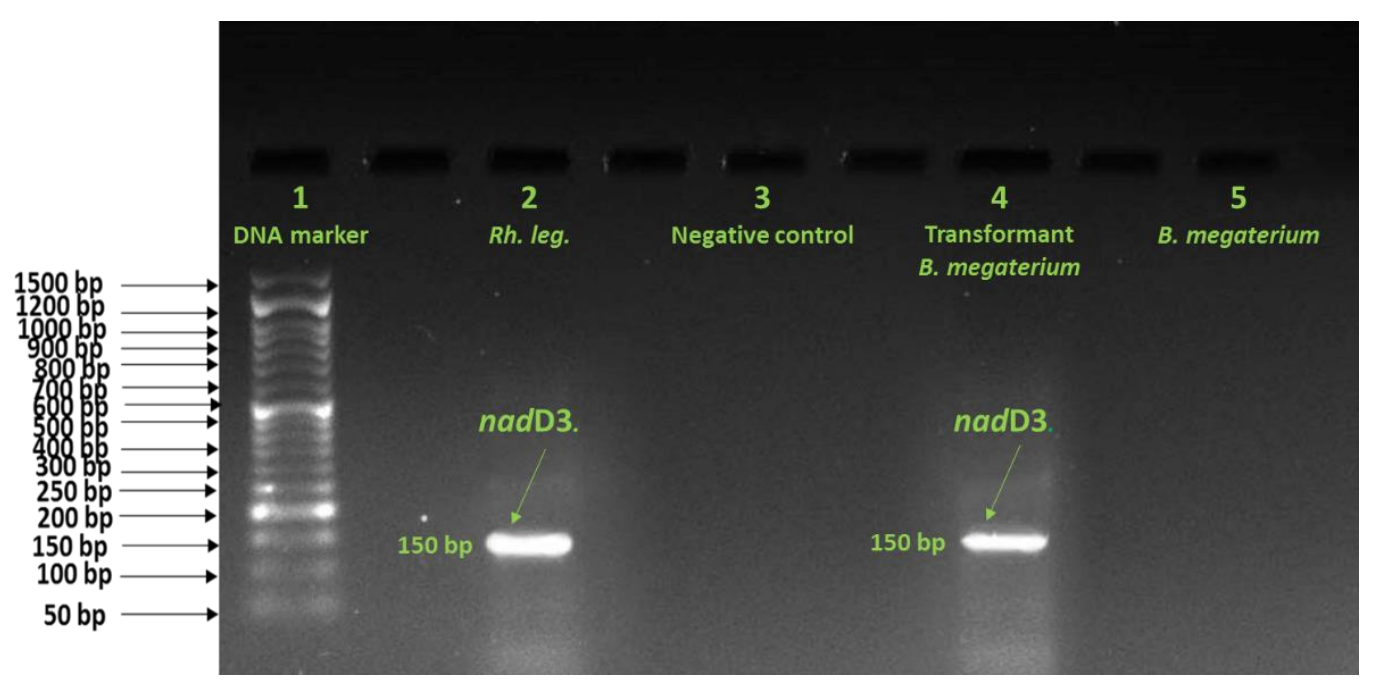

Figure 4. Agarose gel electrophoresis shows the PCR amplified products of the nodD3 gene (150 bp). Lane 1: DNA marker, lane 2: R. leguminosarium (+ve PCR product), lane 3: negative control (-ve PCR product), lane 4: transformant B. megaterium (+ve PCR product) and lane5:

B. megaterium (-ve PCR product)

\section{Transferring of chromosomal genes (nifH2 and nifH3) from A. chroococcum to transformant $B$. megaterium by conjugation process}

Conjugation experiment was done between A. chroococcum as donor cells and transformant $B$. megaterium as recipient cells to investigate the transference ability of nitrogen fixation genes (nifH genes) which were nif $\mathrm{H} 2$ and nif $\mathrm{H} 3$ from isolated $A$. chroococcum to transformant B. megaterium. A. chroococcum was successful in conjugation technique with transformant $B$. megaterium, and (166) transformantconjugant colonies were obtained on Sperber's agar plates containing ampicillin and 
erthymycine. In order to confirm the mobilization of nitrogen fixation genes (nif $\mathrm{H} 2$ and nifH3) from donor to recipient, a molecular study using PCR technique and gel electrophoresis was done for detecting these genes in each of $A$. chroococcum, $B$. megaterium, and transformant-conjugant $B$. megaterium.

\section{PCR amplification of nifH2 and nifH3}

After extraction and purification of genomic DNA from A. chroococcum, $B$. megaterium and transformant-conjugant $B$. megaterium using the PrestoTM Mini gDNA Bacteria Kit according to the manufacturer's protocol, PCR was performed for amplification of nif $\mathrm{H} 2$ and nif $\mathrm{H} 3$ via the use of specified oligonucleotide primers that flanked the DNA sequence to be amplified, and gel electrophoresis was carried out in order to check the presence of nifH2 and nifH3 in the chromosomal DNA of $A$. chroococcum, B. megaterium, and transformant-conjugant $B$. megaterium.

Results in Figure 5 indicated that A. chroococcum and transformant-conjugant $B$. megaterium samples which contained nif $\mathrm{H} 2-\mathrm{F}$ and nif $\mathrm{H} 2-\mathrm{R}$ primers exhibit positive PCR products of nif $\mathrm{H} 2$ on the gel in lanes 2 and 4 respectively with $(250 \mathrm{bp})$. Also the results in Figure 6 indicated that the gel electrophoresis shows positive amplification of nifH3 (130 bp) in A. chroococcum and transformant-conjugant B. megaterium samples using nifH3 -F- and nifH3 -R- primers and they produced clear bands in lanes 2 and 4, respectively, while $B$. megaterium and negative control were shown negative PCR products in lanes 3 and 5, respectively and they did not produce bands in Figures 5 and 6.

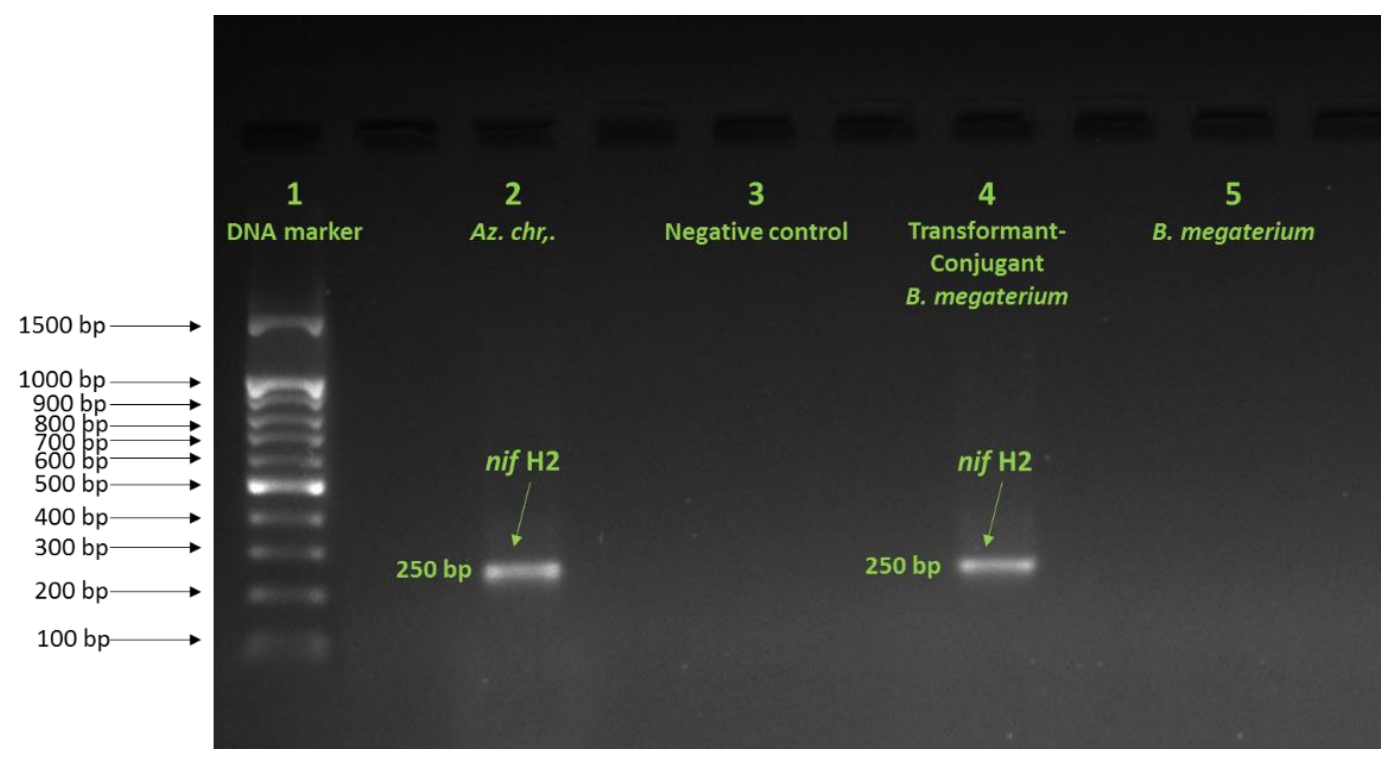

Figure 5. Agarose gel electrophoresis shows the PCR amplified products of the nifH2 gene (250 bp). Lane 1: DNA marker, lane 2: A. chroococcum (+ve PCR product), lane 3: negative control (-ve PCR product), lane 4: transformant-conjugant B. megaterium (+ve PCR product) and lane5: B. megaterium (-ve PCR product)

\section{Discussion}

This research work was carried out to find out the transference ability of nodD2 and nod $\mathrm{D} 3$ genes from $R$. leguminosarium by transformation technique, and nif $\mathrm{H} 2$ and 
nifH3 genes from $A$. chroococcum by conjugation process, to the $B$. megaterium in order to obtain a new model of $B$. megaterium which can then be used as a biofertilizer that provides available nitrogen and phosphorus for plants. NodD genes act as a family of regulatory genes (Kidaj and Wielbo, 2010). The nod genes are controlled by nodD genes, nodD proteins act as transcriptional activators of inducible nod genes (Kumari and Sinha, 2011). NifH acts as dinitrogenase reductase, obligate electron donor to dinitrogenase during dinitrogenase turn over and are required for FeMo-Co biosynthesis and apodinitrogenase maturation (Shamseldin, 2013). The region of chromosome which contain nifK, nifD, nifM, nifA, nifN, nifB, nifQ, nifZ, nifP, nifF, nifW, nifB, nifL and nifY genes are located between the fragment of chromosome which contains nifH1, nif $\mathrm{H} 2$, nif $\mathrm{H} 3$ and the fragment containing nif $\mathrm{V}$, nifS and nif $\mathrm{U}$ (Hamilton et al., 2011). So the importance of the nod $\mathrm{D}$ genes which are located on the plasmid, and nif $\mathrm{H}$ genes which are located between fragments of chromosomal DNA, and their role in nitrogen fixation process gave importance to our choice of these genes for this study.

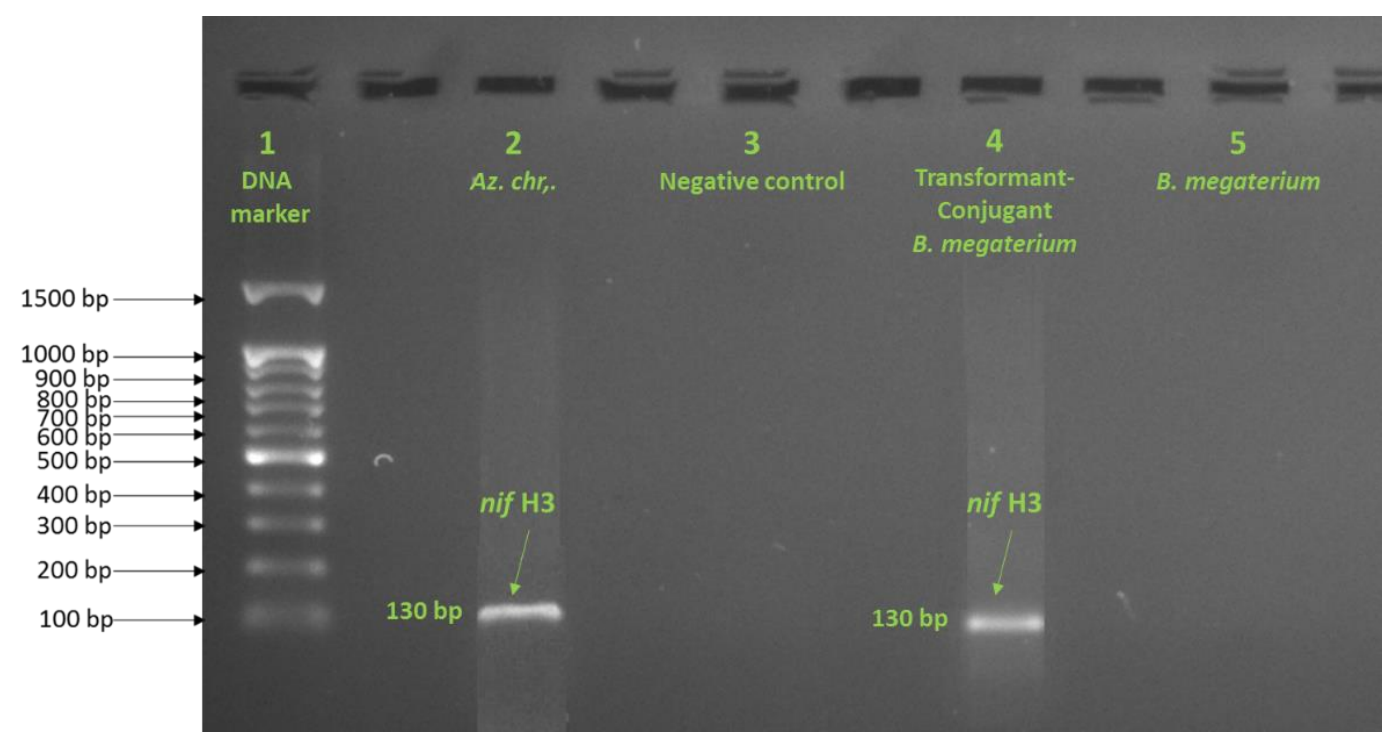

Figure 6. Agarose gel electrophoresis shows the PCR amplified products of the nifH3 gene (130 bp). Lane 1: DNA marker, lane 2: A. chroococcum (+ve PCR product), lane 3: negative control (-ve PCR product), lane 4: transformant-conjugant B. megaterium (+ve PCR product) and lane5: B. megaterium (-ve PCR product)

Firstly, R. leguminosarium, A. chroococcum and B. megaterium were isolated and identified by classical and molecular approach, classical approach included cultural, morphological and biochemical tests (the results did not show), while molecular characterizations of isolated bacteria based on the detection of genomic DNA of $B$. megaterium and A. chroococcum and the plasmid DNA of $R$. leguminosarium, have been successfully applied (Fig. 1 lanes 2, 4, 6 respectively), and PCR technique and gel electrophoresis were carried out to detect and check the presence of $B$. megaterium by using two random primers 1 and 2 . The banding patterns were intense, clear and reproducible which confirmed the existence of $B$. megaterium in the region (Fig. 2) lanes 2 and 3. Previous studies by Shiva et al. (2010) and Patil et al. (2013) indicated the presence of $B$. megaterium in a different area by these primers. Also the molecular study to identify $R$. leguminosarium was depended on the detection of the nod 2 
nodD3 on the plasmid using specific complementary primers by PCR technique and gel electrophoresis, because nodulation genes (nod genes) are located on the plasmid which is also called mega plasmid. Kumari and Sinha, 2011; Giraud et al., 2007 indicated that the common nodulation genes (nod ABCD) are found in all bacteria that nodulate legumes, and Black et al. (2012) reported that all fourteen species of Rhizobium contained nodD, as well Rossen et al. (1985) showed and confirmed the presence of nod $\mathrm{D}$ in $R$. leguminosarium, and for the detection of the nif $\mathrm{H} 2$ and nif $\mathrm{H} 3$ in the $A$. chroococcum using specific complementary primers to amplify them, PCR and gel electrophoresis were carried out after extracting the genomic DNA of the $A$. chroococcum. Previous studies by Dashti (2011), Khider (2012), Abid (2013) and Mohamed (2017) proved the existence of different nif $\mathrm{H}$ genes in A. chroococcum in some regions of Kurdistan. Iraq.

The transformation technique was based on the extraction of the plasmid from $R$. leguminosarium and preparation of the competent cells from B. megaterium in order to transfer nod $\mathrm{D} 2$ and nod 3 genes from $R$. leguminosarium to $B$. megaterium, The process succeeded when 12 colonies were gotten on Sperber's agar plates containing tetracycline and ampicillin which were used as genetic markers, these transformant colonies may be due to transferring the plasmid DNA from $R$. leguminosarium to $B$. megaterium, to confirm that, PCR technique and gel electrophoresis were carried out to amplify and detect the presence of the nodD2 and nodD3 genes in each of $R$. leguminosarium, $B$. megaterium and transformant $B$. megaterium using specific complementary primers after extracting the plasmid DNA from them. The results presented in Figures 3 and 4 showed positive PCR products of nodD2 with $100 \mathrm{bp}$ and nod $\mathrm{D} 3$ with $150 \mathrm{bp}$ for $R$. leguminosarium in lane 2 and transformant $B$. megaterium in lane 4, and negative PCR products for negative control in lane 3 and B. megaterium in lane 5 and they did not produce any bands, these results indicated that the plasmid transferred to transformant bacteria by transformation process. Mohamed (2017) also transferred nodC from $R$. leguminosarium to $B$. megaterium by the transformation technique and proved the success of the process between these two bacteria.

Based on these results, the conclusion is that the plasmid with all the nod genes $(\operatorname{nod} \mathrm{A}, \operatorname{nod} \mathrm{B}, \operatorname{nod} \mathrm{C} \operatorname{nod} \mathrm{D}, \operatorname{nod} \mathrm{E}, \operatorname{nodF}, \operatorname{nod} \mathrm{G}, \operatorname{nod} \mathrm{I}, \operatorname{nod} \mathrm{M}, \operatorname{nod} \mathrm{P}$, and other $\operatorname{nod}$ genes) were transferred to the $B$. megaterium and all of them expressed and encoded for nitrogen fixation process in transformant cells, because all of them were located on the plasmid DNA. Plasmid transformation into bacterial competent cells is a key in molecular cloning technique (Tu et al., 2005). Plasmids are replicating circular pieces of DNA, they are smaller than the bacterial genome which encoded their transfer by replication into another bacterial strain or species. They can carry and transfer multiple resistance genes, which may be located on a section of DNA capable of transfer from one plasmid to another or to the genome-transposon or jumping gene (Snyder and Champness, 1997). Chemical transformation includes the usage of calcium chloride, this mode of transformation is easy to perform and requires a minimum number of equipment (www.himedialabs.com a). Because bacteria hosts are not readily convertible to transgenic cells, they need to be treated chemically with calcium chloride and physically with heat shock (Jones \& Bartlett Learning, LLC., 2016). Cohen and his colleges in 1973 successfully transformed R-factor and recombinant plasmids into $E$. coli cells using a calcium chloride method, since that time this method has been widely used due to its convenience (Tu et al., 2005). 
The conjugation technique was based on the transfer of nif $\mathrm{H} 2$ and nif $\mathrm{H} 3$ genes from A. chroococcum which acted as donor cells to B. megaterium which acted as recipient cells. The process succeeded when 166 colonies were obtained on Sperber's agar plates containing ampicillin and erthymycine that were used as genetic markers. The growth of the transformant-conjugant colonies may be due to the formation of the conjugation bridge between the donor and recipient bacteria and transmission of ori $\mathrm{T}$ genes across this bridge (Snyder and Champness, 1997). To prove the completion of the conjugation process, PCR technique and gel electrophoresis were carried out to amplify and detect the presence of the nif $\mathrm{H} 2$ and nifH3 genes in each of $A$. chroococcum, B. megaterium and transformant-conjugant $B$. megaterium using specific complementary primers. The results in Figures 5 and 6 showed positive PCR products of nif $\mathrm{H} 2$ with $(250 \mathrm{bp})$ and nifH3 with $(130 \mathrm{bp})$ for $A$. chroococcum in lane 2 and transformant-conjugant $B$. megaterium in lane 4 , and negative PCR products for negative control in lane 3 and $B$. megaterium in lane 5 and they did not produce any bands. The conjugation technique of nif genes have been proved and reported previously by Davis et al. (2000) when they transferred many nif genes from A. chroococcum to Klebsiella pneumonia and they observed the expression of these genes in transconjugant bacteria, while Khider (2011) and Dashti (2011) transferred some chromosomal nif genes by conjugation from $A$. chroococcum to Lactobacillus planetarium, also Mohamed (2017) proved this process by transferring some chromosomal nif genes from A. chroococcum to B. megaterium. Many bacteria from different species frequently exchange their genetic materials by a conjugation process which occurs by cell-to-cell contact. This process has been extensively studied because of its significance in genetic manipulation studies (Fernandez-Lopez et al., 2005) as well as in horizontal gene transfer and the resulting spread of multiple antibiotic resistance and virulence.

\section{Conclusion}

As a result, the two techniques: transformation to transfer nodD2 and nodD3, and conjugation to transfer nif $\mathrm{H} 2$ and nifH3 to Bacillus megaterium cells were succeeded perfectly. The aim of the presented manuscript is to obtain a new bacteria containing beneficial genes besides its advantageous genes that can be used as an important biofertilizer to plants. Our recommendation is using a new Bacillus megaterium bacteria that received nod and nif genes as a biofertilizer for providing nitrogen by two methods and solubilized phosphorus for plant nutrition, and improving the quality and quantity of plants.

Acknowledgment. We wish to thank Assistant Professor Dr. Zaid Khalaf Khidhir and Professor Dr. Nawroz Abdul-razzak Tahir from the Faculty of the Agricultural Sciences University of Sulaimani for their cooperation.

\section{REFERENCES}

[1] Abid, S. A. (2013): Microbiological and molecular biology study of Azotobacter species from Bakrajow soil in Sulaimani. - M.Sc. Thesis. Faculty of Agricultural Sciences, University of Sulaimani, Kurdistan.

[2] Acharya, T. (2013): Gene transfer mechanism in bacteria and its types. - Microbe Online. Xinqipolymer.com. 
[3] Agrawal, P. K., Agrawal, S., Singh, U., Katiyar, N., Verma, S. K. (2012): Phenotypic characterization of rhizobia from legumes and its application as a bioinoculant. - Journal of Agricultural Technology 8(2): 681-692.

[4] Agrilife. Biosolutions for Soils \& Crops (2008): Bacillus megaterium BioFertilizer, approved for use in organic agriculture. - www.agrilife.in.

[5] American Type Culture Collection (2013): Antibiotic and selection reagent usage for resistant E. coli cells. - www.atcc.org.

[6] Ausabel, F. M., Brent, R., Kingfton, R. E., Moore, D. D., Feidman, J. G., Smith, J. A, Ftruhl, K. (2003): Current Protocol Molecular Biology. 1st Ed. - John Wiley and Sons, Inc, New York.

[7] Black, M., Moolhuijzen, P., Chapman, B., Barrero, R., Howieson, J., Hungria, M., Bellgard, M. (2012): The Genetics of Symbiotic Nitrogen Fixation: Comparative Genomics of 14 Rhizobia Strains by Resolution of Protein Clusters. - Genes 3: 138-166. DOI: 10.3390. www.mdpi.com/journal/genes.

[8] Cocking, E. C. (2003): Endophytic colonization of plant roots by nitrogen-fixing bacteria. - Plant and Soil 252(1): 169-175.

[9] Cohen, S. N., Chang, A. C., Boyer, H. W., Helling, R. B. (1973): Construction of biologically functional bacterial plasmid in vitro. - National Academy of Sciences of the Unites States of America 70(11): 3240-3244.

[10] Das, M., Raythata, H., Chatterjee, S. (2017): Bacterial transformation: What? Why? How? and When? - Annual Research \& Review in Biology 16(6): 1-11.

[11] Dashti, A. M. K. (2011): Isolation and Characterization of Azotobacter spp. - Ph.D. thesis: Erbil Soils, and Study the Effect of Biofertilzer (Azotobacter chroococcum and transconjugant Lactobacillus plantarum) on Nutrient Uptake by Wheat. Ministry of High Education and Scientific Research, University of Salahaddin/Erbil, Kurdistan.

[12] Davis, N., Cannon, L., Wilson, A., Williams, T. (2000): Expression of Azotobacter nitrogen fixation genes (nif) in Klebsiella. - J. Gen. Microbiol. 105(4): 321-330.

[13] Del Cerro, P., Rolla-Santos, A. A. P., Gomes, D. F. Marks, B. B., et al. (2015a). Regulatory nod $\mathrm{D} 1$ and nod $\mathrm{D} 2$ genes of Rhizobium tropici strain CIAT 899 and their roles in the early stages of molecular signaling and host-legume nodulation. - BMC Genomics 16(1): 251. DOI: $10.1186 / \mathrm{s} 12864-015-1458-8$.

[14] Del Cerro, P., Rolla-Santos, A. A. P., Gomes, D. F. Marks, B. B, et al. (2015b). Opening the "black box" of nod D3, nod D4 and nod D5 genes of Rhizobium tropici strain CIAT 899. - BMC Genomics 16: 864. DOI: 10.1186/s12864-015-2033-z.

[15] Deslippe, J., Egger, K. (2006): Molecular diversity of nifH genes from bacteria associated with high arctic dwarf shrubs. - Microb. Ecol. 51: 516-525.

[16] Dixon, R., Kahn, D. (2004): Genetic regulation of biological nitrogen fixation. - Nature Reviews Microbiology 2(8): 621-631.

[17] Fernandez-Lopez, R., Machon C., Longshaw C. M., Martin S., Molin S., Zechner E. L., Espinosa M., Lanka E., de la Cruz, F. (2005): Unsaturated fatty acids are inhibitors of bacterial conjugation. - Microbiol 151: 3517-3526.

[18] Giacopello, C., Foti, M., Mascetti, A., Grosso, F., Ricciardi, D., Fisichella, V., Lo Piccolo, M. F. (2016): Antimicrobial resistance patterns of Enterobacteriaceae in European wild bird species admitted in a wildlife rescue centre. - Veterinaria Italiana 52(2): 139-144. DOI: 10.12834/VetIt.327.1374.2.

[19] Giraud, E., Moulin, L., Vallenet, D., Barbe, V., Cytryn, E., Avarre, J. C., Jaubert, M., et al. (2007): Legume symbioses: absence of nod genes in photosynthetic bradyrhizobia. Science 316: 1307-1312.

[20] Griffiths, A. F. J., Miller, J. H., Suzuki, D. T., et al. (2000): An Introduction to Genetic Analysis. 7th Ed. - W. H. Freeman and Company, New York.

[21] Hamilton, T. L., Marcus, L, Ray, D., Eric, S. B., Patricia, C., et al. (2011): Transcriptional profiling of nitrogen fixation in Azotobzctervinelandii. - J. Bacteriol. 193(17): 44774486. 
[22] Hausner, M., Wuertz, S. (1999): High rates of conjugation in bacterial biofilms as determined by quantitative in situ analysis. - Applied and Environmental Microbiology 65(8): 3710-3713.

[23] Helmut, B. F., Widmer, W., Sigler, V., Zeyer, J. (2004): New molecular screening tools for analysis of free-living diazotrophs in soil. - Appl. Environ. Microbiol. 70: 240-247.

[24] Jones \& Bartlett Learning, LLC. (2016): Bacterial Transformation. Chap. 1. ShutterStock, Inc., New York.

[25] Jones, K. M., Kobayashi, H., Davies, B. W., Taga, M. E., Walker, G. C. (2007): How rhizobial symbionts invade plants: the Sinorhizobium-Medicago model. - Nat. Rev. Microbiol. 5: 619-633.

[26] Kennedy, I. R., Islam, N. (2001): The current and potential contribution of a symbiotic nitrogen fixation to nitrogen requirement on farms: a review. - Australian Journal of Experimental agriculture 42: 441-457.

[27] Khider, A. K. (2011): Chromosomal nif genes transfer by conjugation in nitrogen fixing Azotobacter chrococcum to Lactobacillus planetarium. - Current Research Journal of Biological Sciences 3: 155-164.

[28] Khider, A. K. (2012): Molecular study of nifH1, nifH2, nifH3, nifU, nifV, VF genes and classical approach cared out to identification of Azotobacter chrococcum from soil. Curr. Res. J. Biol. Sci. 4(5): 570-577.

[29] Kidaj, D., Wielbo, J. (2010): Use of Rhizobial Nod Factors as Biofertilizers for Legumes. - M. Curie-Skodowska University, Lublin, Poland. Mikkeli, Finland.

[30] Kumari, S., Sinha, R. P. (2011): Symbiotic and Asymbiotic N2 Fixation. Chap. 5. - In: Sinha, R. P. et al. (eds.) Advances in Life Sciences. I. K. International Publishing House Pvt. Ltd., New Delhi.

[31] Lerouge, P., Roche, P., Faucher, C., Maillet, F., Truchet, G., Promé, J., Dénarié, J. (1990): Symbiotic host-specificity of Rhizobium meliloti is determined by a sulphated and acylated glucosamine oligosaccharide signal. - Nature 344: 781-784.

[32] Marwa, A. S., Elbaz, A. F., Ragab, A. A., Hamza, H. A., El Halafawy, K. A. (2010): Identification and characterization of Azotobacter chroococcum isolated from some Egyptian soils. - J. of Agricultural Chemistry and Biotechnology 1(2): 93-104.

[33] Mohamed, A. S. A. (2017): Molecular study on isolated Azotobacter, Rhizobium and Bacillus megaterium var phosphaticum employment as biofertilizer. - Ph.D. thesis. Salahaddin University-Erbil, Kurdistan.

[34] Moses, P. B. (1987): AppendixGene Transfer Methods Applicable to Agricultural Organisms. - National Center for Biotechnology Information, U.S. National Library of Medicine, Bethesda, MD.

[35] Nosheen, A., Bano, A., Ullah, F., Farooq, U., Yasmin, H., Hussain, I. (2011): Effect of plant growth promoting rhizobacteria on root morphology of Saffl ower (Carthamus tinctorius L.). - African Journal of Biotechnology 10(59).

[36] Olsen, J., Brown, D., Baggesen, D. L., Bisgaard, M. (1992): Biochemical and molecular characterization of Salmonella enterica serovar berta, and comparison of methods for typing. - Epidemiology and Infection 108: 243-260.

[37] Patil, H. S. R., Patil, Naik, T. V., Avin, B. R. V., Sayeswara, H. A. (2013): Isolation and molecular characterization of Bacillus megaterium isolated from various agro climatic zones of Karnataka and its effect on medicinal plant Ruta gradiolus. - Curr Res Microbiol Biotechnol. 1(4): 173-182.

[38] Pimda, W., Bunnag, S. (2010): Genetic transformation of Vanda lilacina Teijsm \& Binnend. with a chitinase gene. - AAB Bioflux 2(1): 71-78.

[39] Rossen, L., Shearman, C. A., Johnston, A. W. B., Downiel, J. A. (1985): The nodD gene of Rhizobium leguminosarum is autoregulatory and in the presence of plant exudate induces the nod A, B, C genes. - The EMBO Journal 4(13A): 3369-3373.

[40] Sambrook, J., Fritsch, E., Maniatis, T. (1989): Laboratory Manual of Molecular Cloning. Vol. 3. - Cold Spring Harbor, New York. 
[41] Setubal, J. C., Santos, P. D. Goldman, B. S. Ertesvåg, H. Espin, G. et al. (2009): Genome sequence of Azotobacter vinelandii, an obligate aerobe specialized to support diverse anaerobic metabolic processes. - J. Bacteriol. 191: 4534-4545.

[42] Shamseldin, A. (2013): The role of different genes involved in symbiotic nitrogen fixation - review. - Global Journal of Biotechnology \& Biochemistry 8(4): 84-94.

[43] Shiva, R. D. M., Mohan, B. K., Nataraja, S., Krishnappa, M., Abhilash, M. (2010): Isolation and molecular characterization of Bacillus megaterium isolated from different agro climatic zones of Karnataka and its effect on seed germination and plant growth of Sesamum indicum. - RJPBCS 1(3): 614.

[44] Shoukry, A. A., Khattab, A. A. Abou-Ellail, M., El-shabrawy, H. (2013): Molecular and biochemical characterization of new Rhizobium leguminosarum bio viciae strains isolated from different located of Egypt. - J. Appl. Sci. Res. 9(11): 5864-5877.

[45] Siddiqui, A., Shivle, R., Magodiya, N., Tiwari, K. (2014): Mixed effect of Rhizobium and Azotobacter as biofertilizer on nodulation and production of chick pea, Cicer arietinum. Biosci. Biotech. Res. Comm. 7(1): 46-49.

[46] Slonczewski, J. (2006): Bacterial Gene Exchange and Mobile Genes. - KAP Genetics and Development, Biology Dept., Kenyon College.

[47] Snyder, L., Champness, W. (1997): Molecular Genetic of Bacteria. - AMS Press, Washington, DC.

[48] Spaink, H. P., Kondorosi, A., Hooykaas, P. (1998): Molecular biology of model plantassociated bacteria. - The Rhizobiaceae XXIV: 566.

[49] Tu, Z., He, G., Li, X. K., Chen, J. M., Chang, J., Yao, Q., Liu, P. D. et al. (2005): An improved system for competent cell preparation and high efficiency plasmid transformation using different Escherichia coli strains. - Electronic Journal of Biotechnology 8(1).

[50] Velineni, S., Brahmaprakash, G. P. (2011): Survival and phosphate solubilizing ability of Bacillus megaterium in liquid inoculants under high temperature and desiccation stress. J. Agr. Sci. Tech. 13: 795-802.

[51] www.explorer.bio-rad.com. Biotechnology_Explorer@bio-rad.com. Biotechnology Explorer. pGLO ${ }^{\mathrm{TM}}$ Bacterial. Transformation Kit.

[52] www.himedialabs.com.a. mb@himedialabs.com. HiPer ${ }^{\circledR}$ Transformation Teaching Kit. Product Code: HTBM017.

[53] www.himedialabs.com.b mb@himedialabs.com. HiPer® Bacterial Conjugation Teaching Kit. Product Code: HTM004.

[54] www.towson.educse. Version (2016): The transformation Lab. Experiment Using E. coli and pFluoroGreen. Based on a kit produced by EDVOTEK®. Adapted by Towson University.

[55] Yoo, L. (2010): The Effect of rpoH for heat shock gene expression on plasmid transformation. - Journal of Experimental Microbiology and Immunology (JEMI) 14: 108-111. 